\title{
空調試運転時を対象とした実測・数值シミュレーションによる 自然換気量評価
}

流量制御機能を有する給排気口を設置したオフィスビルにおける 自然換気及び空調システムの併用手法に関する研究（第一報）

\section{EVALUATION OF NATURAL VENTILATION RATE BY FIELD MEASUREMENT AND NUMERICAL SIMULATION DURING PRE-ACCEPTANCE PHASE \\ Hybrid air-conditioning system using natural ventilation in an office building with flow control inlets and outlets (Part 1)}

\section{安永龍一*, 芦谷友美**, 白石靖幸***, 打川芳恵****, 中村 靖**** Ryuichi YASUNAGA, Yumi ASHITANI, Yasuyuki SHIRAISHI, Yoshie UCHIKAWA and Yasushi NAKAMURA}

\begin{abstract}
A numerical model of the natural ventilation rate based on thermal and air flow network analyses was proposed for a building with flow control inlets and outlets. The prediction accuracy of this model was verified through a comparison with field measurements of a hybrid A/C system in an existing office building, which was being broken-in during the pre-acceptance phase. Moreover, the influence of the flow control function at the inlets and outlets on the natural ventilation rate, and the contributions of buoyancy and wind forces to the natural ventilation rate, were clarified by applying this numerical model to a case study. The following results were obtained: 1) The calculation errors in measurements of natural ventilation rate were less than $10 \%$, and so predictions by this model with flow control had sufficient accuracy. 2) Flow control functions provided a considerable contribution to the ventilation rate, in particular the backflow control function of the outlets was influential. 3) Buoyancy force caused by internal heat load also provided a considerable contribution to the ventilation driving force, and the contribution became especially large under calm outdoor conditions.
\end{abstract}

Keywords : Office building, Natural ventilation, Flow control, Field measurement, CFD analysis, Thermal and air flow network analysis オフィスビル，自然換気，流量制御機能，実測，CFD 解析，熱・換気回路網解析

\section{1. 序}

我が国のオフィスビルでは、急速な OA 化と相俟って内部負荷が 増加し続け、室内における快適性確保のためにアクティブな空調設 備に頼る傾向が続いている。一方、持続可能型社会の実現を目指す 風潮の中、外気の有効利用によってオフィスの内部負荷を効果的に 除去することで冷房負荷を低減させる方法が模索されてきた。近年 では、自然換気と機械冷房を合理的に併用することで室内温熱環境 や空気質環境を快適に保ちながら省エネを達成する手法（以下、八 イブリッド空調システム)が提案され実際に用いられており、BEMS (Building and Energy Management System) による建物全体の消 費エネルギー・温熱環境を考慮した自然換気制御や、効果的な外気 導入を行うための給排気口の流量制御等がなされている。しかし同 システムにおける自然換気量は建物の形状、立地環境、気象条件な どの外界条件に大きく依存し、またシステムの複雑化も相俟ってそ の定量的評価は困難となっている。ハイブリッド空調システムに関 しては既に幾つかの研究がなされており、本田ら 1) は、ダブルスキ
ンを有するオフィスビルにおいて、時間あるいは環境条件によって 各種の換気口・空の開閉等を制御する熱・換気回路網解析を行い、 自然換気による冷房負荷削減効果等の推計を行っている。水出ら 2 3 は、ハイブリッド空調システムにシーリングファンを付加したシス テムを提案し、同システムを導入したオフィスビルを対象に運用段 階における実測調查・実験により基本性能を示すと共に、 HASP/ACLD を用いた年間熱負荷シミュレーションによって、同シ ステムによる年間の泠房負荷削減効果等を示している。また近本・ 張ら $\left.{ }^{4 \sim 6}\right)$ は、CFD 解析によりオフィス内の気流・温度・空気質等の 評価を行い、室内温度分布生成による冷房負荷削減効果を考慮した 年間エネルギーシミュレーションを行っている。更に、細井・須永 ら 7 9) は一般事務所を対象とした実測により、その通風性能を明ら かにすると共に、通風可能な外部条件等の検討も行っている。しか しながら流量制御機能を有する給排気口を設置した実在オフィスビ ルを対象に、実測、更には数值シミュレーションによる性能検証を 行っている研究事例は殆じなく、同システムにおける自然換気量や

\footnotetext{
本論文は既に発表した文献17）、18）加筆・修正したものである。

* 北九州市立大学大学院国際環境工学研究科 大学院生

** 前田建設工業

(研究当時 北九州市立大学大学院 大学院牛)

*** 北九州市立大学国際環境工学部 教授・博士 (工学)

**** 新日鉄エシジニアリング(敇)
}

Graduate Student, Graduate School of Environmental Engineering, The Univ. of Kitakyushu Maeda Corporation, M. Eng.

Prof., Faculty of Environmental Engineering, The Univ. of Kitakyushu, Dr. Eng. Nippon Steel Engineering Co., Ltd. 
省エネ効果の定量的評価に関しては、未だ検討の余地があると言え る。

本研究では、オフィスビルにおいてハイブリッド空調システム、 更には流量制御機能を有する給排気口を導入する場合の自然換気性 状及び省エネ効果を定量的に示すことを主たる目的としている。本 報はその第一報として、外界条件及び給排気口の流量制御機能を再 現した自然換気量の解析モデルの提案を行い、実在するオフィスビ ルの空調試運転時 (入居前) を対象とした実測との比較により、解 析モデルの予測精度の検証を行う。また本解析モデルを用いたケー ススタディを行うことによって、給排気口の流量制御機能の有無に よる換気量の差異や、風力及び浮力の両駆動力の換気量に対する寄 与を明確にする。次報以降では同オフィスビルの運用段階を対象と して、BEMSによる自然換気の実行制御や内部負荷スケジュール等 を再現した解析を試み、実測結果との比較によって、その精度検証、 更には省エネ効果の推計等も行う。

\section{2. 対象建物の概要}

表 1 に対象建物の概要を、図 1 図 3 に建物外観、建物の南北断 面図 (自然換気経路)、基準階平面図をそれぞれ示す。対象建物は福 岡県北九州市にある地上 5 階建て、両端コアのオフィスビルであり、 1 階はエントランスや会議室、2～5 階は執務空間となっている。本 建物は平成 21 年度「次世代省エネルギー等建築システム実証事業」 （NEDO）に採択されており、2030 年のゼロ・エネルギー・ビル （ZEB）化を目指した実証事業が進められている。省エネ技術とし て、ハイブリッド空調システムの他、太陽光発電システム、昼光利 用システム等の様々な技術が導入されている。また執務室はエリア 毎に適切な空調制御を行うため、高効率ビルマルチ空調（天井吹き 出し, 天井吸い込み）を導入し、空調熱源として一部は地中熱利用 HP、その他は空冷 HP を採用している。建物全体では BEMS が導 入されており、建物内外のセンサー情報に基づいて室内環境を制御 すると共に建物の機器・設備等を自動管理することで、それらのエ ネルギー消費量の削減を図っている。

自然換気経路としては、図 3 に示すように、各階の南北（全面ガ ラスカーテンウォール) 床レベルに設置された給気口より外気が導 入され、導入された外気は室中央の吹き抜けを介し、建物上部の換 気塔に設けられた排気口より排気される仕組みとなっている。建物 周辺は春から秋にかけてこの地区特有の南風と北風が吹く。特に対 象建物の南側に遮蔽物が無いことから、南風時の誘引効果による風 力換気を意図した設計となっている。図 4 及び図 5 に給気口及び排 気口をそれぞれ示寸。各給気口位置（図 3 に示寸ように、1 フロア あたり南北 5 箇所設置) には図 6 に示寸開口が計 3 つある。給気口 は、図 15 (後述) に示す $\mathrm{P}-\mathrm{Q}$ 特性（メーカー提供データ）を有し ており、差圧に応じて流量を制御することで過剩な外気の流入を防 ぐことが可能である。また排気口には逆流防止機能が備わっており、 排気口を介する建物内外の差圧が負（逆流）になると対応する排気 口が閉じる仕組みとなっている。尚、本建物では自然換気有効・無 効の条件に基づき BEMS による給排気口の開閉の自動制御が行わ れるが、本報にて検討対象とした空調試運転時は手動制御により自 然換気を常時許可している。
表 1 対象建物概要

\begin{tabular}{c|l}
\hline \hline 所在地 & 福岡県北九州市戸畑区 \\
\hline 構造 & $\mathrm{S}$ 造,両端コア \\
\hline 階数 & 地上 5 階 (最高高さ: $27.40 \mathrm{~m})$ \\
\hline 延床面積 & $10,388 \mathrm{~m}^{2}$ \\
\hline 敷地面積 & $6,649,401 \mathrm{~m}^{2}$ \\
\hline 竣工 & 2010 年 12 月 \\
\hline \hline
\end{tabular}

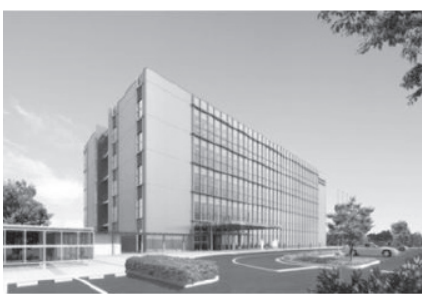

図 1 建物外観

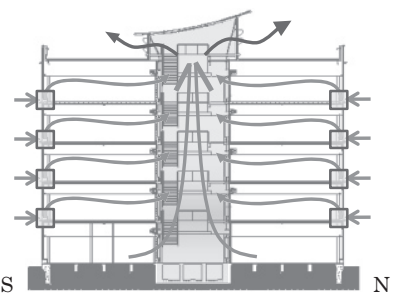

図 2 断面図（自然換気経路）

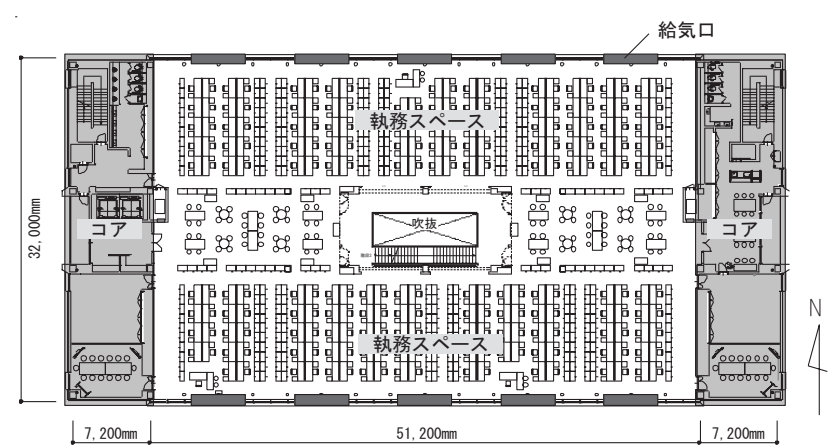

図 3 基準階平面図

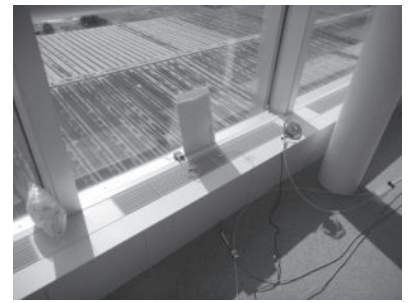

図 4 給気口

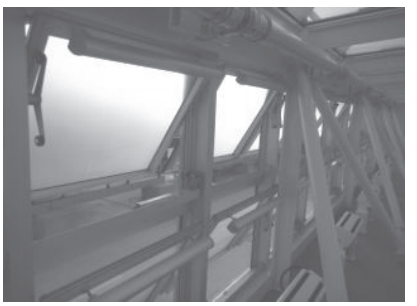

図 5 排気口

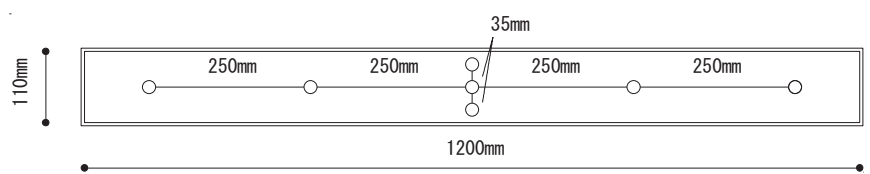

図 6 給気口形状及び風速分布の測定ポイント

\section{3. 実測概要}

本実測は入居前の空調試運転期間である 2010 年 11/6 11/11 に おいて、対象建物 4 階の執務空間と執務空間の中央にある吹き抜け 空間を対象注 1) とし、自然換気量の測定を行った。その際、測定精 度を高めるため、他階と吹き抜け部を仕切る防火シャッターを閉め ることで測定対象外の空間との漏気を極力防ぐように配慮している。 また実測期間中は冷房を行っていない。測定項目及び測定機器を表 2 に示す。一般に実測レベルでは十分な測定精度を確保した自然換 気量の測定は困難であるため、本実測では1 1 トレーサーガス法(一定 発生法)、(2)給気口の風速值を用いた推定法の 2 手法による測定を同 時に行った。尚、対象は大空間となるため、4 階の南側のみ給気口 を開いた場合（Case A：11/8～9） と北側のみ給気口を開いた場合 （Case B : 11/10〜11）の2 ケースにおいて測定を行った。両手法の 
測定間隔は 10 分とした。また(1)トレーサーガス法による測定の際 は、トレーサーガスが十分に拡散するようにドージングポイント及 び空間全体にサーキュレータを設置している。(2)給気口の風速值を 用いた推定法の場合、給気口内の風速分布を考慮した測定を行うべ きであるが、測定機器数や精度等の問題から各給気口の中心 1 点の 風速值から給気口の面積を乗じて換気量を推定する方法を採用した。 ただし、同推定方法の精度検証並びに補正方法に関しては、予備実 測にて各給気口内の風速 7 点（図 6）を多点風速計により詳細に測 定し、事前に検討を行っている注 2) (Case C : 11/6〜 7)。この詳細 測定は、南北面の中央と両端に位置する計 6 箇所の給気口を対象と して行い、給気口の位置による風速分布の傾向も同時に把握してい る。図 7 に Case A,B 及び C の測定ポイントを示す。ペリメータに おける日射負荷の把握のため、室内側の南北鉛直面の日射量を測定 した。インテリアでは照明の消費電力量注3) BEMS データより把 握した。その他、外気温湿度も BEMS データより、風向・風速は北 九州市八幡地区の気象庁観測データ 10) よりそれぞれ入手した。

\section{4. 実測結果}

Case A 及び B の実測期間中における外気温湿度と室内側の南北 鉛直面日射量を図 8 に、屋外風速及び風向を図 9 に示す。外気温は 概ね $11 \sim 20^{\circ} \mathrm{C}$ であり、主風向は 11/8 11/10 が西、11/11 が南、風 速は概ね $0 \sim 8 \mathrm{~m} / \mathrm{s}$ の範囲内であった。

4-1 給気口内の風速分布を考慮した換気量の推定（Case C)

図 7(b)中の $\mathrm{a}$ 及び $\mathrm{b}$ 地点における給気口内 7 点の風速值の面積加 重平均值注 2) と中央 1 点の風速值との相関図を図 10 に示す。 2 つの 風速值には正の相関が見られ、決定係数も非常に高い。このことよ

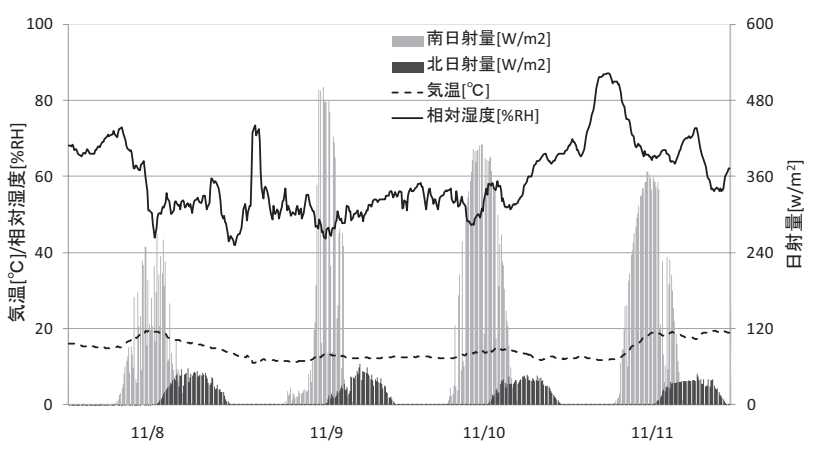

図 8 外気温湿度及び南北鉛直面日射量

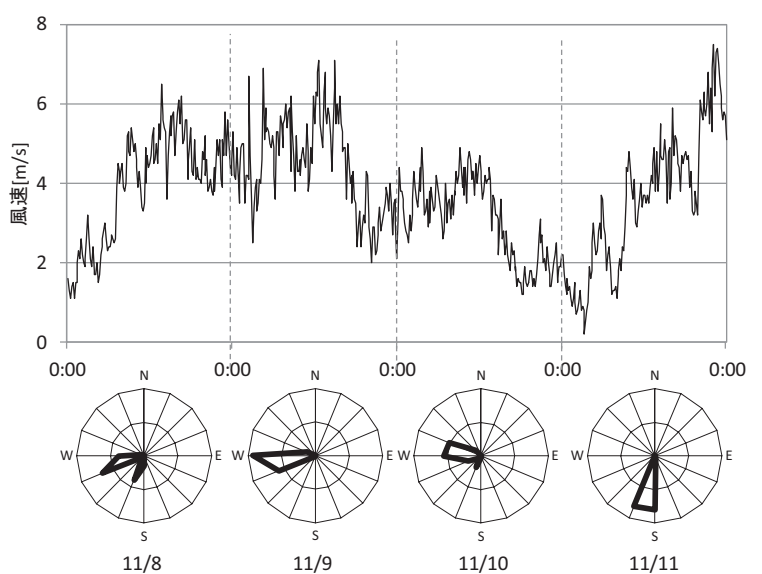

図 9 屋外風速及び風向
り、各給気口の風量を算出する際、中央 1 点の代表風速から算出す るのではなく、図中に示寸補正式を使用することにより、多点で測 定を行った風速值と同等に、比較的高精度に風量を推定できること が示唆された。また、他の $\mathrm{c} \sim \mathrm{f}$ 地点の給気口でも同様の結果（推定 式）が得られているため、以下、(2)給気口の風速值を用いて換気量 を推定寸る場合には、各給気口中央の風速值と推定式を用いて算出 した值を使用する。

\begin{tabular}{|c|c|}
\hline 測定項目 & 測定機器 \\
\hline 屋外気象条件 & $\begin{array}{l}\text { 外気温湿度 : BEMS } \\
\text { 風向・風速 : 気象庁観測データ 10）（八幡） }\end{array}$ \\
\hline 換気量 & $\begin{array}{l}\text { 光音響マルチガスモニター } 1412-5 \text { 型, } \\
\text { マルポイントサンプラ・ドーザ } 1303 \text { 型 } \\
\text { INNOVA, トレーサーガス : R-134a }\end{array}$ \\
\hline 給気口の風速 & 多点風速計 MODEL1550／KANOMAX \\
\hline $\begin{array}{c}\text { 日射量 } \\
\text { (室内側の南北鈆直面) }\end{array}$ & ML-020VM／英弘精機 \\
\hline
\end{tabular}

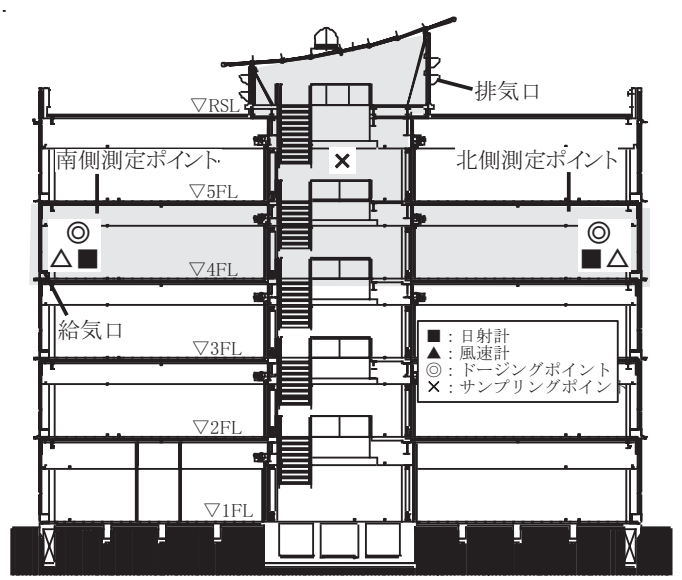

(a)南北断面図

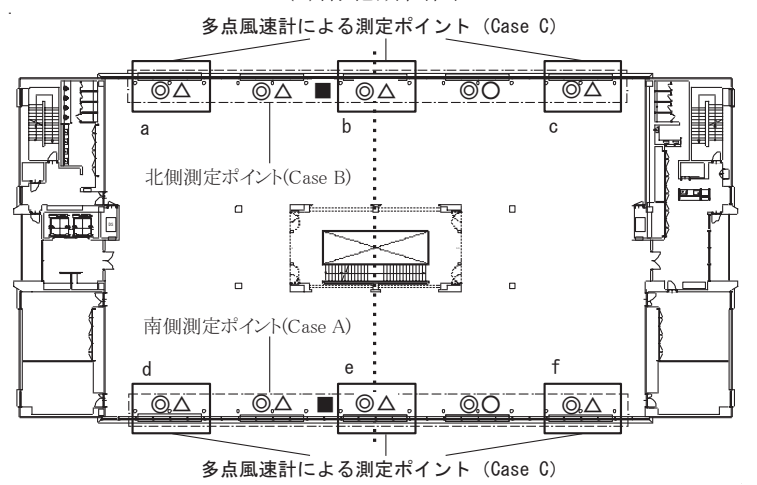

(b) 4 階平面図

図 7 測定ポイント

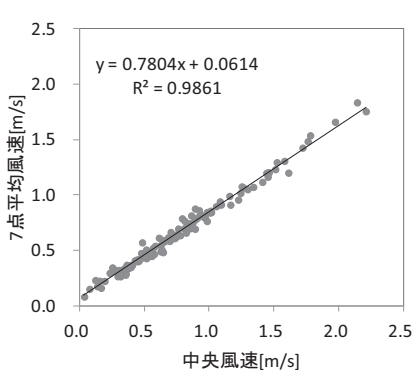

(a) a 地点

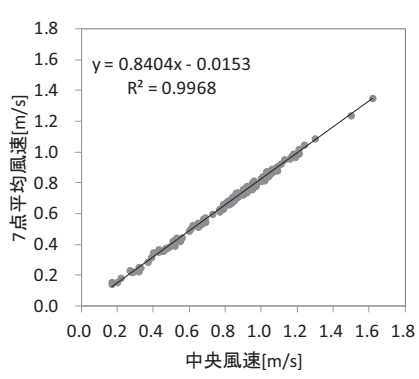

(b) b 地点
図 10 面積加重平均值と中央風速値の比較（測定ポイント $\mathrm{a}, \mathrm{b}$ ) 


\section{4-2 換気量の測定 (Case A, B)}

(1)トレーサーガス法及び(2)給気口の風速值を用いた推定法による 自然換気量の測定結果を図 11 に示寸。図に示寸通り、両手法の測 定結果は経時変化の傾向は概衫対応寸るものの、(1)のトレーサーガ ス法による測定結果の方が(2)の風速值を用いた推定法よりも数割程 度、換気量を大きく評価する傾向にある。これは、今回の実測が空 調試運転時に行われたため、試運転作業や更には什器の搬入等によ って、防火シャッター部を含めたドア等の開閉が頻繁に行われ、他 の階からの漏気や給排気口以外の想定していない開口部へのトレー サーガスの排出等が生じたためと推察される。一方、(2)の風速值を 用いた推定法に関しては、前述の通り風速值の補正を行っており、 給気口からの外気導入量としては、比較的高い精度の数值であると 考えられる。上記の通り、実測期間中は 4 階の給気口以外から外気 導入もしくはトレーサーガスの排出がなされていた点や両手法の測 定精度を勘案すると(2)の風速值を用いた推定法による結果が、給気 口からの外気導入量を精度良く捉えているものと推察される。よっ て、以降の解析における精度検証の際には(2)の值を用いる。

図 12 及び図 13 に $11 / 9$ における自然換気量(2)の風速值による推 定值）と室内側南北鉛直面の日射量及び屋外風速の関係をそれぞれ 示す。今回の測定では、換気量は日射量や屋外風速とは別の要因 (例 えば、給排気口の流量制御機能や風向）に強く影響を受け、結果と して図に示寸通り、日射量や屋外風速との相関がなかったものと考 えられる（R2 值はそれぞれ 0.02、0.04）。

\section{5. 解析概要}

数值シミュレーションにより自然換気量を高精度に予測するには 建物内外の空間を CFD 解析により同時に解く等の精緻な対応が必 要となるが、今回のような大規模なオフィスビルで長いタイムスケ ールを対象とするような場合は現実的ではない。また給排気口の開 閉制御等を再現するにはより簡便な手法が望ましい。一方、熱・換 気回路網解析では年間の非定常解析を行うことが可能となり、また フィードバック制御を組み込むことで給排気口の開閉等が再現でき るが、導入外気の動圧が室内空間にて保存されるような条件下での 適用には、予測精度の点で問題がある 11-12)。しかし、今回対象とし た建物では南北の外皮面積に対する給気口の面積比は極めて小さく、 また全ての給気口は流量制御機能を有しているため、室内気流の動 圧は殆ど消散される注4)。よって本研究では、自然換気量の評価には 熱・換気回路網解析 $\left.{ }^{13}\right)$ を採用する。ただし、事前に対象建物及び 周辺建物を再現した CFD 解析注5)（屋外 CFD 解析）を行うことで 対象建物の給排気口位置における 16 風向別の風圧係数を算出し、 これを熱・換気回路網解析に反映させることで同解析手法の高精度 化を試みている。また本解析ではフィードバック制御を用いること で給排気口の流量制御機能を再現している。

\section{$5-1$. 屋外 CFD 解析}

表 3 に解析条件を、図 14 に解析モデルをそれぞれ示す。図 14 に 示すように建物周辺を含む広領域を計算の対象とし、開口を再現し ていないモデル（建物内の換気経路の解析を行わないモデル）を用 いて 16 風向別に給気口と排気口の開口位置における風圧係数の算 出を行う。流入面の鉛直風速分布は $1 / 5$ べき乗則注6 を仮定しており、 流出面は表面圧力を $0 \mathrm{~Pa}$ と設定した。

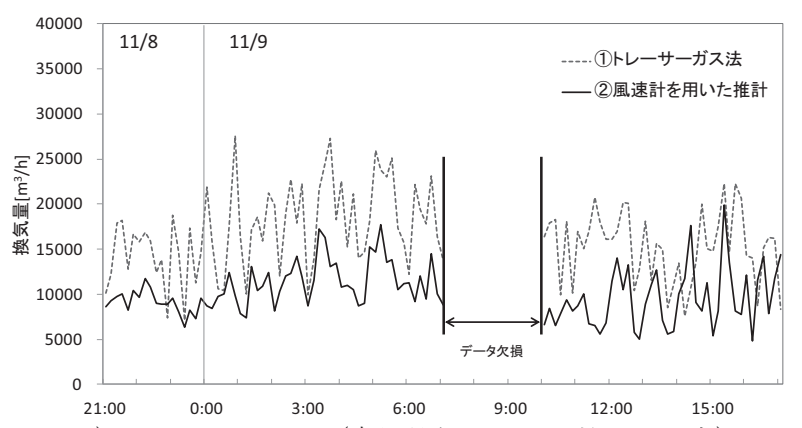

a) Case A：10/8〜9 (南側給気口のみ開放した場合)

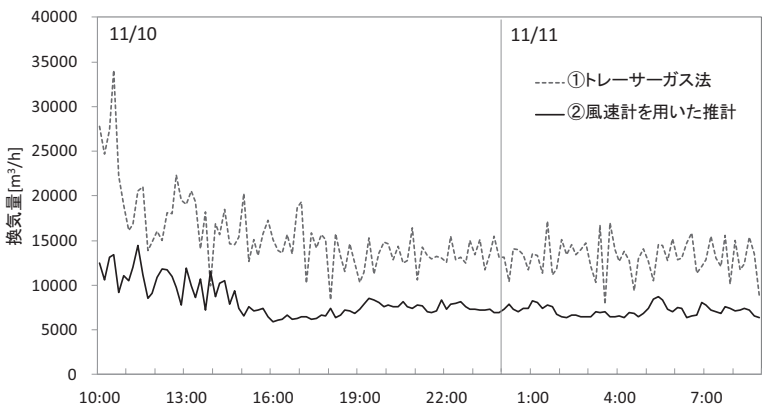

b) Case B：10/10〜 11 (北側給気口のみ開放した場合) 図 11 換気量の測定結果

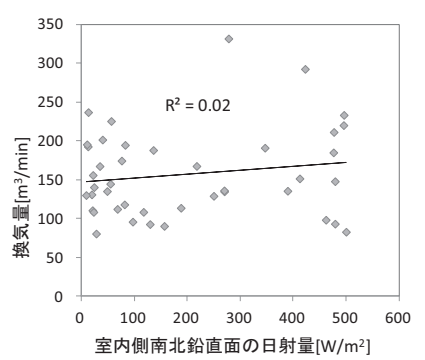

図 12 換気量と日射量の関係

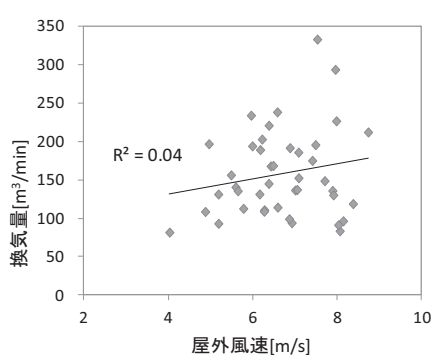

図 13 換気量と風速の関係

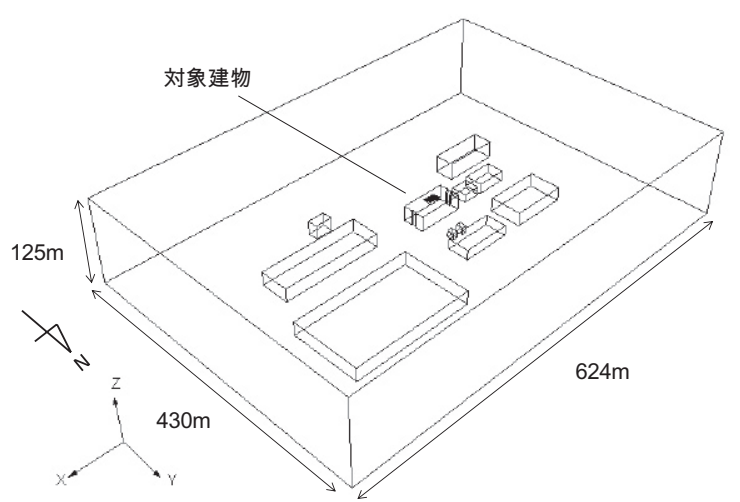

図 14 屋外 CFD 解析モデル

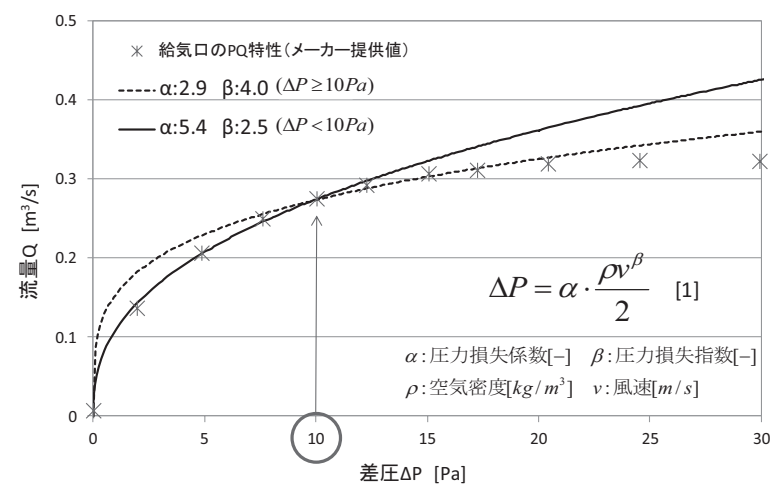

図 15 給気口の $\mathrm{P}-\mathrm{Q}$ 特性 


\section{5-2. 熱・換気回路網解析}

本解析では屋外 CFD 解析にて求めた風圧係数を各給排気口に与 え、実測時の条件下 (Case A,B) にて熱・換気回路網解析を行い、 実測值と比較することで解析モデルの予測精度の検証を行う。次に、 ケーススタディとして表 5 に示す通り、それぞれの実測ケース （Case A,B）に対して、1）給排気口の流量制御機能を再現しない場 合注 7)（CaseA-1,B-1）及び 2）浮力を考慮しない場合注 8) (CaseA-2,B-2) の解析を行い、各要因の対象建物の自然換気性状一 の寄与を定量的に評価する。

熱・換気回路網解析の条件を表 4 に示寸。対象建物の東西（コア 部）及び上下階は断熱であると仮定し、 $4 \mathrm{~F}$ 及び吹抜け部を解析対象 として、10 分間隔の非定常計算を行った。室内発熱として日射（実 測値）及び照明による発熱量を与えており、実測期間中は常時照明 を ONにしていたため照明による発熱量は一定值（38.5 kW）とし た。以下ではフィードバック制御による給排気口の流量制御手法の 概要を示す。

\section{（1）給気口の流量制御機能}

本解析では、給気口の圧力損失係数及び指数の異なる二つの換気 回路を作成し、給気口を介寸る内外の圧力差に応じて換気回路（圧 力損失係数 $\alpha[-]$ 及び指数 $\beta[-])$ をフィードバック制御により切り替 えることで給気口の $\mathrm{P}-\mathrm{Q}$ 特性を再現している。図 15 に給気口の $\mathrm{P}-\mathrm{Q}$ 特性及び解析にて用いた 2 パターンの $\alpha$ 及び $\beta$ の組み合わせを示し ている。室内外の差圧 $10 \mathrm{~Pa}$ を判定値として $10 \mathrm{~Pa}$ 末満であれば $\alpha$ $=5.4, \beta=2.5$ とし、 $10 \mathrm{~Pa}$ 以上であれば $\alpha=2.9, \beta=4.0$ としている。 $10 \mathrm{~Pa}$ 以上の場合、差圧 $\Delta \mathrm{p}$ が大きくなると解析值の方がメーカー 提供值よりも若干大きくなる傾向にあるが、本解析における給気口 の平均差圧は 8.6 Pa、標準偏差 $4.7 \mathrm{~Pa}$ 、最大值 $28.8 \mathrm{~Pa}$ であったた め、換気量の予測精度には殆ど影響しないものと考えられる。本解 析におけるフィードバック制御機能の概念図を図 16 に示す。フィ ードバック制御では 1 ステップ前の結果（室内外の差圧等）に基づ き、回路網を選択して解析を行っている。そのため、非定常時にお ける 1 ステップの計算時間間隔を大きくすると解析が安定せず、適 切な結果が得られない可能性がある。本解析を行うにあたり、計算 時間間隔を 30 分、 15 分、10 分に変化させた解析を事前に行い、 15 分と 10 分の解析結果では差異が殆ど無いことを確認している。よ って、本解析では計算時間間隔として 10 分を採用している。

（2）排気口の流量制御機能

排気口の逆流防止機能についても図 16 と同様のロジックによっ て、排気口を介寸る内外の差圧が負 (逆流)になれば流路面積が $0 \mathrm{~m}^{2}$ となるような解析を行い、実現象を再現している。尚、排気口の圧 力損失係数及び指数は、メーカー提供值を参考にして $\alpha=2.4 、 \beta=2.0$ と設定している。

\section{6. 解析結果}

\section{$6-1$. 屋外 CFD 解析結果}

図 17 に 4 階南北中央の給気口位置及び屋上南北中央の排気口位 置における風圧係数を示す。また図 18 及び図 19 に南北風向時にお ける建物周辺の水平面風速分布及び鉛直面静圧分布をそれぞれ示す。 図 17 の (a)(b)を比較すると、風向が北の場合においても北側の給気 口の風圧係数が小さい(図 17(b))。これは対象建物の北側に多く建物

表 3 屋外 CFD 解析条件

\begin{tabular}{|c|c|}
\hline 流入面 ${ }^{14)}$ & 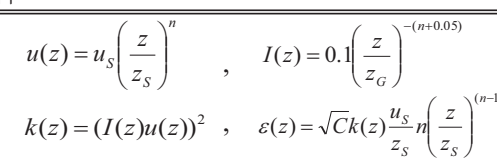 \\
\hline 流出面 & 表面圧力(圧 $: 0[\mathrm{~Pa}])$ \\
\hline 乱流モデル & LK モデル 15) \\
\hline 上空面・側面 & Free-slip \\
\hline 地表面 & $1 / 5$ 乗則壁面応力境界 \\
\hline 建物表面 & 一般化対数則 \\
\hline 解析領域 & $624 \mathrm{~m}(\mathrm{x}) \times 430 \mathrm{~m}(\mathrm{y}) \times 125 \mathrm{~m}(\mathrm{z})$ \\
\hline 要素数 & $1,815,068: 181(\mathrm{x}) \times 109(\mathrm{y}) \times 92(\mathrm{z})$ \\
\hline
\end{tabular}

$u(z)$ : 流入風速の鈆直分布 $[\mathrm{m} / \mathrm{s}], u_{S}$ : 基準高さ $z_{S}$ における風速 $(=2.0)[\mathrm{m} / \mathrm{s}]$, $z_{S}:$ 基準高さ $(=20)[\mathrm{m}], \quad z$ : 地表面からの高さ $[\mathrm{m}], \mathrm{n}$ : ぶき数 $(=5)$, $I(\mathrm{z})$ :乱れ強さの鈆直分布 $[-], z_{G}$ : 上空風高度 $(=450)[\mathrm{m}], k(\mathrm{z}):$ : 乱流エネル ギーの鈆直分布 $\left[\mathrm{m}^{2} / \mathrm{s}^{2}\right], \varepsilon(\mathrm{z}): k(\mathrm{z})$ の散逸率 $\left[\mathrm{m}^{2} / \mathrm{s}^{3}\right], C:$ モデル定数 [-]

表 4 熱・換気回路網の解析条件

\begin{tabular}{|c|c|}
\hline 気象データ & $\begin{array}{l}\text { 外気温: BEMS データ注 9) (図 8) } \\
\text { 風速, 風向 : 気象庁観測データ注 9) (図 9) }\end{array}$ \\
\hline 計算期間 & $\begin{array}{l}\text { 2010/11/08 11/09(Case A : 南側のみ開) } \\
\text { 2010/11/10 11/11(Case B : 北側のみ開) }\end{array}$ \\
\hline 室内発熱 & $\begin{array}{l}\text { 日射：実測值（図 8) } \\
\text { 照明：BEMS データ（38.5kW） }\end{array}$ \\
\hline 節点数(熱回路) & 117 点 \\
\hline 流路数(換気回路) & 給気 10 流路, 排気 6 流路 \\
\hline 計算間隔 & 10min（非定常） \\
\hline
\end{tabular}

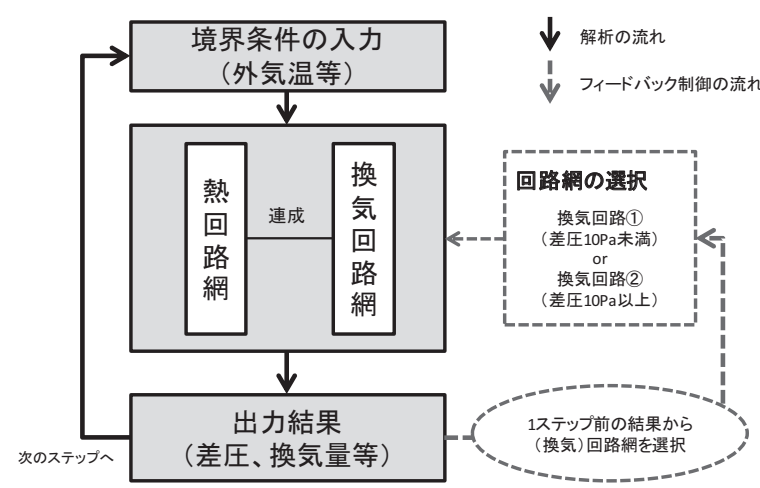

図 16 フィードバック制御の概念図

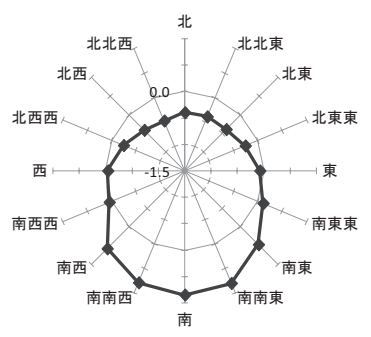

(a) $4 \mathrm{~F}$ 南側中央の給気口

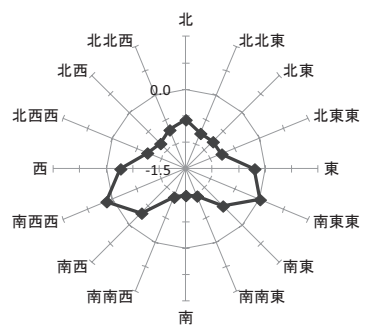

(c) 屋上南側中央の排気口

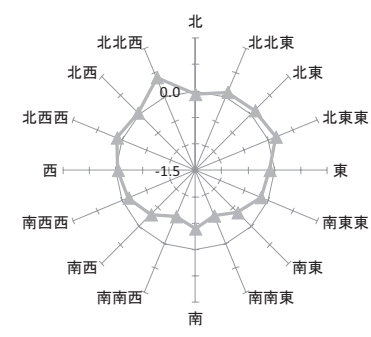

(b) $4 \mathrm{~F}$ 北側中央の給気口

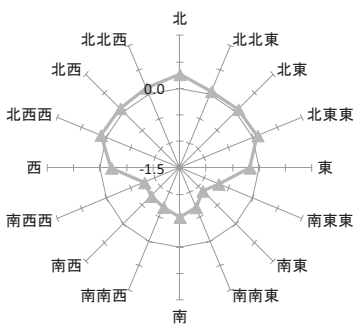

（d）屋上北側中央の排気口

図 17 各開口部における風圧係数の一例 
が立地していることが原因と考えられ、図 18(b)より対象建物の北 側に位置する建物の影響で対象建物北側の風速が減衰している様子 を確認できる。

一方、図 17 の $(\mathrm{c})(\mathrm{d})$ における排気口の風圧係数をみると、風向が 南の場合においても南側の排気口の風圧係数の方が小さい(図 17(c))。これは対象建物の南側に建物が無く開けていることが理由 として考えられる。図 19 に示寸通り(b)の風向が北の場合よりも(a) の南の場合の方が剥離の影響によって建物上部及び換気塔周辺の圧 力が低くなっている様子が確認できる。

以上のことから、本建物においては設計意図通り、風向が南の場 合に効果的に自然換気が行えるものと推察される。

\section{$6-2$. 予測精度の検証}

実測期間中における給気口の風量平均值 $\left[\mathrm{m}^{3} / \mathrm{h}\right]$ の実測值及び解析 值を表 5 に示す。また給気風量 $\left[\mathrm{m}^{3} / \mathrm{h}\right]$ の実測值と解析值(Case $\mathrm{A}, \mathrm{B}$ ) の時系列変化を図 20 に示寸。尚、図中には流量制御無しの場合の 解析結果(CaseA1, B1)も併せて示している。表 5 及び図 20 に示寸通 り、風量平均值ベースの実測值との誤差が Case A で+7.0\%、Case B では-4.5\%程度となっており、また給気風量の時系列変化もその傾 向を良く捉え、再現している。

以上より、対象期間において本解析モデルにより精度良く自然換 気量を予測できることが確認できた。また建築基準法に基づく計算 式より算出した必要換気量は $6553.6\left[\mathrm{~m}^{3} / \mathrm{h}\right.$ ] (床面積 $1638.4 \mathrm{~m}^{2}$ 、占 有面積 $5.0 \mathrm{~m}^{2} /$ 人、換気回数換算 1.4 回 $/ \mathrm{h}$ ）であり、図 20 を見ると 南北どちらかの給気口を閉じた条件下であっても、概袐必要換気量 を満たしていることが確認できる注 11 )。

\section{$6-3$. 給排気口の流量制御機能の寄与}

図 20 に示寸通り Case A,B と流量制御機能を再現していない Case A1,B1 注7) を比較すると CaseA1,B1 の方がともに風量平均值 が低い值を示している。これは特に排気口の逆流防止機能によって Case A では 20.8(=13.8+7.0)\%、Case B では 11.4(=15.9-4.5)\%程度、 風量の低下が抑制されているためである。また図 20 における風量 の実測值の推移をみると、図 20(a)では風量が大きく変動している が、図 20(b)の後半では風量が安定している。これは、実測期間の 前半 (図 9 参照) は卓越風向が西（給排気口面に平行）であるため、 風向のわずかな変化に応じて排気口の風圧係数が大きく変化し、排 気口の開閉が頻繁に切り替わった結果、風量が大きく変動したもの と推察される。一方、図 20 の解析值の Case A 及びA1 では、使用 した風向・風速の気象データが 1 時間毎であるため注 9 )、全体的に 挙動が緩やかとなる傾向にある。ただし、排気口が常に開いている Case A1 では、Case A よりも風量のピーク值が抑制される。

以上より、流量制御機能を解析に考慮することによって実際の自 然換気の挙動を概ね再現できることを確認した。

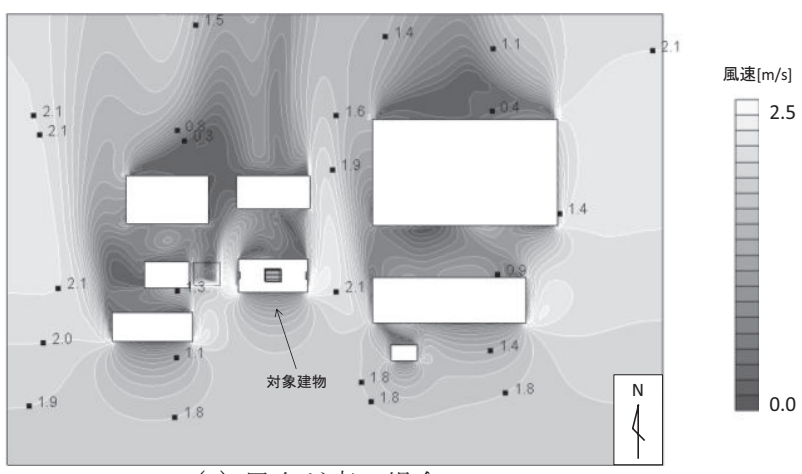

（a）風向が南の場合

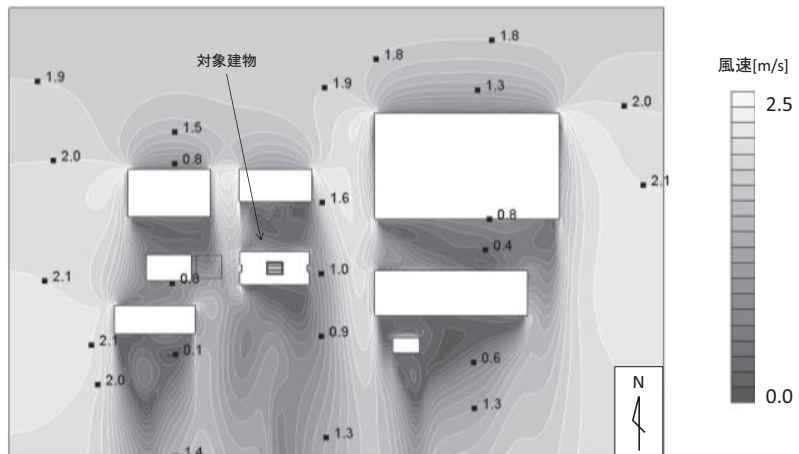

（b）風向が北の場合

図 18 水平面風速分布 $(\mathrm{Z}=13.5 \mathrm{~m})$

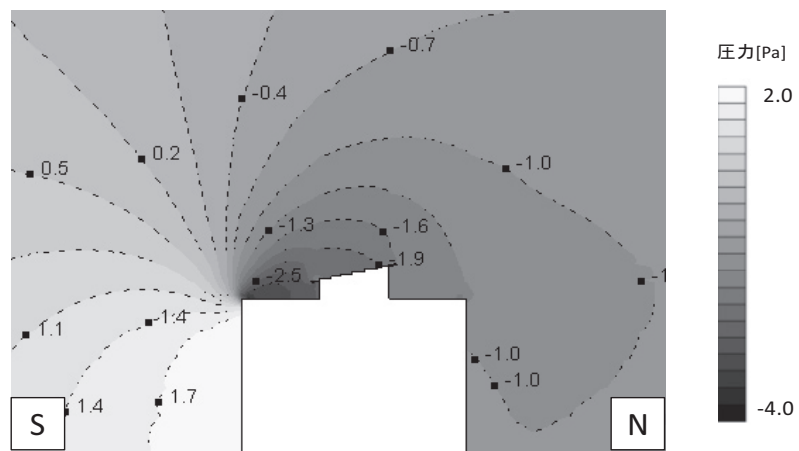

（a）風向が南の場合

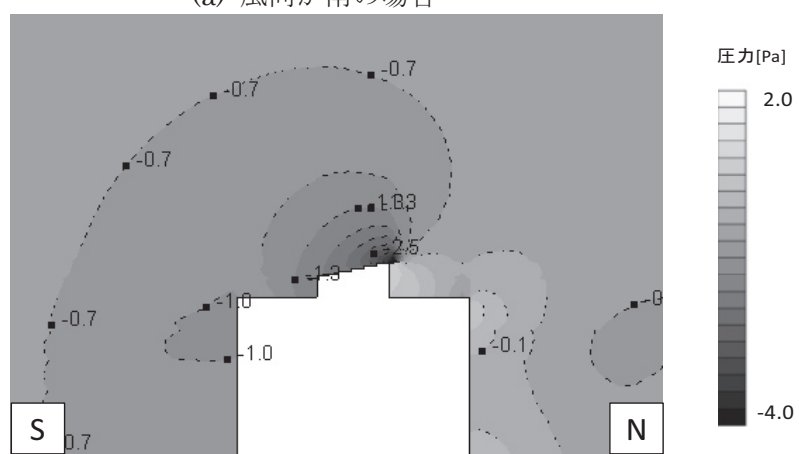

（b）風向が北の場合

図 19 南北鉛直面の静圧分布 $(X=153 m)$

表 5 解析ケース及び給気口の風量平均値の結果

\begin{tabular}{|c|c|c|c|c|c|}
\hline 解析ケース & ケースの説明 & $\begin{array}{l}\text { 風量平均値 } \times 10^{2} \\
{\left[\mathrm{~m}^{3} / \mathrm{h}\right] \text { (実測值) }} \\
\end{array}$ & $\begin{array}{l}\text { 風量平均値 } \times 10^{2} \\
{\left[\mathrm{~m}^{3} / \mathrm{h}\right] \text { (解析值) }}\end{array}$ & $\begin{array}{c}\text { 風量平均値の } \\
\text { 実測値との差[\%] }\end{array}$ & $\begin{array}{c}\mathrm{RMSE} \text { 注 } 10) \times 10^{2} \\
{\left[\mathrm{~m}^{3} / \mathrm{h}\right]}\end{array}$ \\
\hline Case A & 流量制御有り & 102.5 & 109.5 & +7.0 & 33.5 \\
\hline Case A1 & 流量制御無し & 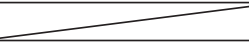 & 88.3 & -13.8 & 34.0 \\
\hline Case A2 & 浮力無し & 工 & 94.9 & -7.4 & 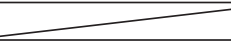 \\
\hline Case B & 流量制御有り & 99.0 & 94.6 & -4.5 & 14.7 \\
\hline Case B1 & 流量制御無し & 2 & 83.3 & -15.9 & 21.0 \\
\hline Case B2 & 浮力無し & 2 & 67.1 & -32.2 & 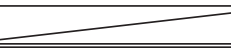 \\
\hline
\end{tabular}




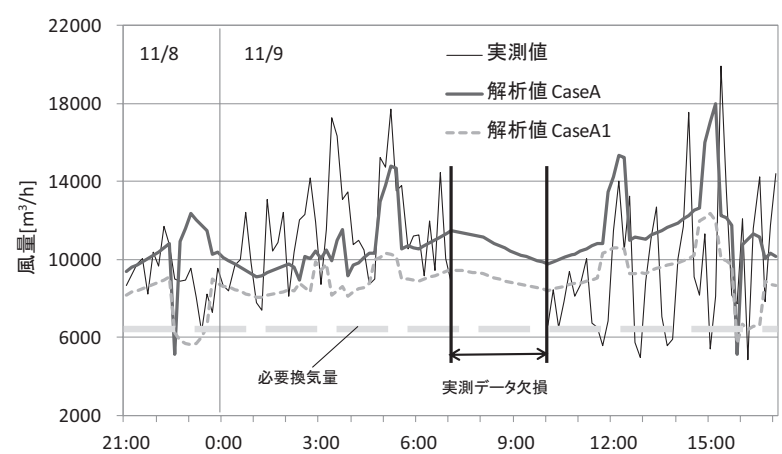

(a)南側のみ給気口を開いた場合

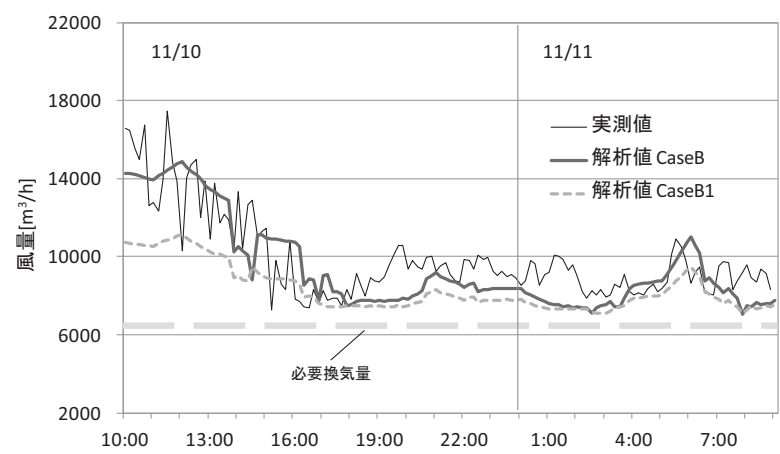

(b)北側のみ給気口を開いた場合

図 20 給気口風量の時系列変化（実測值との比較）

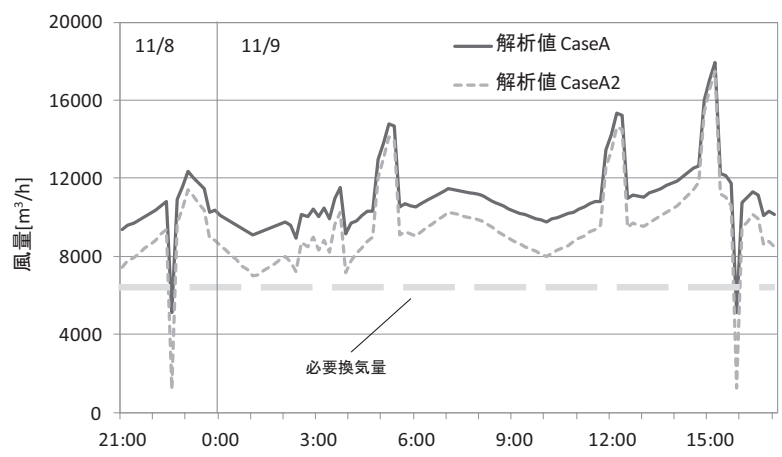

(a)南側のみ給気口を開いた場合

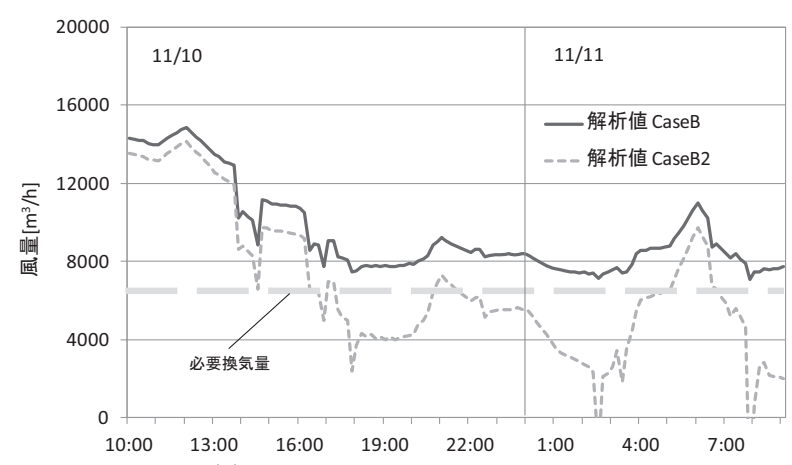

(b)北側のみ給気口を開いた場合

図 21 給気口風量の時系列変化（浮力なしの場合との比較）

\section{$6-4$. 浮力と風力の寄与}

図 21 に Case A,B 及び Case A2,B2（浮力無し）の給気風量の時 系列変化を示す。図 21(a) では実測期間中の風速が常に $4 \mathrm{~m} / \mathrm{s}$ 程度と 風力が卓越していたため (図 9 参照)、Case A と Case A2 に大きな 差異は見られない。一方、図 21(b)ではほぼ無風状態となる時間帯
もあるため、浮力を考慮していない Case B2 では風量が一時的に 0 となる。一方、浮力を考慮した Case B の解析では必要換気量を満 たす程度の十分な風量を確保できている。

以上より、外部風による風力が卓越している場合は、浮力による 寄与は小さいが、無風時においては室内発熱による浮力の影響で一 定の換気量が常に確保できることが示唆された注11。

\section{7. 総括}

本報では、ハイブリッド空調システムを採用した実在するオフィ スビルを対象として、給気口及び排気口の流量制御機能を考慮した 自然換気量の解析モデルを提案した。更に、対象建物の空調試運転 時における実測と数值シミュレーションを行い、両結果を比較する ことで解析モデルの精度検証を行うと共に解析によるケーススタデ イを通じて、対象建物の自然換気性状の把握を試みた。以下に得ら れた知見を示す。

1）給気風量の実測值と解析值の誤差が 1 割以下となっており、今 回の条件下では流量制御機能を再現した解析モデルにより精度良 く換気風量を推定できることを確認した。

2）周辺建物の立地及び対象建物上部の形状によって、風向が北の場 合よりも南の場合において効果的に自然換気が行えることが示唆 された。

3）今回の解析条件下では、南側もしくは北側のどちらかの給気口を 閉じた場合においても、ほぼ全ての時間帯において必要換気量を 満たす風量が供給されており、対象建物では自然換気によって十 分な風量を確保できることが示唆された。

4）排気口の逆流防止機能によって、換気量の低下を抑制しているこ とが確認できた。

5）対象建物では、無風時においても室内発熱による浮力の影響によ って一定の換気量が確保されることが確認できた。

今後、対象建物の運用段階における実測及び解析を行い、提案寸 る解析モデルの更なる精度検証を踏まえ、ハイブリッド空調システ ムの省エネ効果の推計等を行う予定である。

\section{謝辞}

本研究を行うにあたり、北九州市役所の大庭慶祐氏(当時、北九州市 立大学大学院生)に甚大なるご協力を頂いた。記して、感謝の意を表 する。

注 1)本実測では自然換気量の測定精度を高めるために、対象空間及び給気口 の開放も南北のどちらかに限定し、更に防火シャッターを閉鎖して対応し ている。ただし、実際の運用段階の換気経路と異なるといった問題も懸念 されるが、本報にて示寸実測の測定精度及び数值シミュレーションの予測 精度の検証結果を踏まえて、次報以降にて運用段階における自然換気量及 び省エネ効果の定量的な検証を行う予定である。

注 2)風速の測定点は給気口 1 箇所あたり 7 点ではあるが、予備測定により給 気口中央部の短辺方向の速度分布は長辺方向においてもほぼ同様の分布を 有するということを確認している。このため、長辺方向の中央を除く 4 箇 所においても中央と同様に短辺方向に速度分布が生じているものと仮定し、 実際には測定を行っていない計 8 点（短辺 3 点 $\times$ 長辺 5 点一実際の測定箇 所 7 点）の風速を推定し、計 15 箅所の面積加重平均值として平均風速の算 出を行っている。 
注 3)入居前の空調試運転時のため $\mathrm{OA}$ 機器等は搬入されておらず、内部負荷 としては照明負荷のみである。

注 4)給気口形状及び流量制御機能を詳細に再現した単室レベルの CFD 解析に よると ${ }^{16)}$ 、室内気流の動圧が殆ど消散し、熱・換気回路網解析の結果と概 ね一致することを確認している。

注 5)株式会社ソフトウェアクレイドルの STREAM ver. 7 を用いた。

注 6)文献 14）を参考に、地表面祖度区分をIII（建築物が密集する地域、ある いは中層建築物が散在している地域）と仮定した。

注 7)流量制御を行わない場合の給気口の圧力損失係数が不明なため、今回の 解析では流量制御なしのケースにおいては、図 8 の $\Delta \mathrm{P}<10 \mathrm{~Pa}$ の圧力損失 係数及び指数（ $\alpha=5.4, \beta=2.5 ）$ を用いた。よって、他のケースで行ってい るような換気回路の切り替えは行っていない。この点は、今後の検討課題 として位置づけている。

注 8)室内発熱（日射及び照明）を０として解析を行った。㛜密には躯体等の 蓄熱による浮力の影響が働いているが、その影響は相対的に極めて小さい。 注 9)外気温、風向・風速共に 10 分間隔で測定を行っているが、解析ツールに 取り込む気象データのフォーマットに合わせて、実際の解析に際しては 1 時間毎のデータを用いた。

注 10)RMSE とは、2 乗平均平方根誤差(Root Mean Square Error)のことで あり、以下の式を用いて算出している。

$\mathrm{RMSE}=\sqrt{\sum_{\mathrm{i}=1}^{\mathrm{n}}\left(\overline{\mathrm{x}}-\mathrm{x}_{\mathrm{i}}\right) / \mathrm{n}} \quad \overline{\mathrm{x}}$ : 実測值, $\mathrm{x}_{\mathrm{i}}$ : 解析值, $\mathrm{n}$ : データ数

注 11)空調試運転時を対象とした解析であるため、OA 機器や人体発熱が本解 析では考慮されていない。よって、運用段階においては換気駆動力である 浮力の寄与がより大きくなるものと推察される。

\section{参考文献}

1）本田公宏 他 4 名：ダブルスキンを有する建物における熱性能シミュレー ションの検討事例, 日本建築学会大会学術講演梗概集, D-2, pp. 231-234, 2001. 08

2) 水出喜太郎 他 6 名：自然換気・シーリングファンを併用した空調換気シ ステムの制御手法と性能評価に関寸る研究, 日本建築学会環境系論文集, 第 604 号, pp. 69-76, 2006.6

3）水出喜太郎 他 6 名：自然換気・シーリングファンを併用した空調換気シ ステムの制御手法と性能評価に関する研究 第 2 報, 日本建築学会環境系 論文集，第 620 号, pp. 59-66, 2007.10

4) 近本智行, 加藤信介, 村上周三他：冷房時のオフィス空間における自然 換気ハイブリッド空調に関する研究 (その $1 \sim 17$ ) , 日本建築学会大会 学術講演梗概集, D-2, pp. 597-598, 1997 ほか

5）張 賢在，加藤信介，村上周三他：オフィスにおける自然換気ハイブリ ッド空調に関する研究（第 1 報）, 空気調和・衛生工学会論文集，No. 83, pp. 81-90, 2001. 10

6）張 賢在, 加藤信介, 村上周三他：オフィスにおける自然換気ハイブリ ッド空調に関する研究（第 2 報），空気調和・衛生工学会論文集，No. 88, pp. $63-72,2003.1$

7）細井昭憲, 成田樹昭, 須永修通: 自然通風に関する実測研究 その 1 風 圧力と浮力が同時に作用する建物における通風特性, 日本建築学会計画系 論文集，第 564 号, pp. 25-31，2003.02

8）細井昭憲, 成田樹昭, 須永修通: 自然通風に関する実測研究 その 2 自 然通風の温熱快適性に基づく制御方法と省エネルギー効果, 日本建築学会 環境系論文集，第 577 号，pp. 7-12，2004.03

9) 細井昭憲, 須永修通, 宮本麻理子, 成田樹昭 : 自然通風に関寸る実測研 究 その 3 建物の熱性能が自然通風の有効性におよぼす影響, 日本建築 学会環境系論文集，第 588 号, pp. 27-34, 2005.02

10）気象庁：気象統計情報,

http://www. jma. go. jp/jma/menu/report. html (2011.12.6)

11）加藤信介 : パワーバランスモデルに基づく通風量計算モデル, 日本建築 学会第 1 回空気シンポジウム, pp. 45-50, 1990

12）樋山恭助, 加藤信介, 高橋岳生, 河野良坪: 開口面積比及び開口位置関 係が通風時気流性状に与える影響の分析, 日本建築学会環境系論文集, 第 596 号, pp. 21-27, 2005. 10

13）奥山博康：熱・換気回路網計算プログラム NETS の検証，IBPSA-Japan, 講演論文集， 2002
14）日本建築学会：市街地風環境予測のための流体数值解析ガイドブック, p. $158,2007.7 .20$

15) Kato, M. and Launder, B.E., The modeling of turbulent flow around stationary and vibrating square cylinders, Proc. of 9 th Symp. Turbulent Shear Flows, (1993), pp. 1041-1046

16）大庭慶祐 他 5 名：オフィスビルにおける自然換気及び機械空調の併用 システムに関する研究，（その 3）マルチスケール CFD 解析による建物全 体の自然換気性状評価, 日本建築学会研究報告 九州支部, 2, 環境系 (50), pp. 309-312, 2011.03

17）安永龍一, 白石靖幸 他 4 名: 北九州市におけるゼロ・エネルギー・ビル を目標とするオフィスビルの性能検証と運用改善,（その4）空調試運転時 における自然換気性状の実測結果, 日本建築学会大会学術講演梗概集, D-2, pp. 1093-1094, 2011

18）安永龍一，白石靖幸 他 4 名: 北九州市におけるゼロ・エネルギー・ビル を目標とするオフィスビルの性能検証と運用改善, （その5）建物内外の 連成解析による自然換気性状評価, 日本建築学会大会学術講演梗概集, D-2，pp. 1095-1096，2011

(2012年 2 月 8 日原稿受理， 2012年 5 月 1 日採用決定） 